\title{
PENGETAHUAN MAHASISWA FAKULTAS ILMU KEOLAHRAGAAN UNIVERSITAS NEGERI SURABAYA TENTANG ALAT OLAHRAGA GYM BALL
}

\author{
Ali Machfud ${ }^{1}$, Febrian Dwi Cahyono를 Muhammad Wahyono ${ }^{3}$ \\ ${ }^{123}$ Jurusan Pendidikan Kepelatihan Olahraga, Universitas Negeri Surabaya, Indonesia \\ *alimachfud18@gmail.com
}

(Received: November 2018 / Revised: January 2018 / Accepted: March 2018)

ABSTRAK: Gym ball adalah alat bantu olahraga yang fokus latihannya pada bagian-bagian tubuh seperti
pantat, paha, punggung belakang, otot perut, bahu, dan dada. Tujuan dari penelitian ini adalah untuk
mengetahui pengetahuan mahasiswa Fakultas Ilmu Keolahragaan universitas Negeri Surabaya tentang alat,
jenis, teknik dan pengetahuan umum yang mempelajari gym ball. Metode dalam penelitian ini adalah
kuantitatif dengan pendekatan deskriptif dengan cara meneliti pengetahuan alat, jenis, teknik dan
pengetahuan umum mahasiswa mengunakan tes angket tertutup dengan mengunakan skala guttman
dengan sampel yang digunakan berjumlah 60 orang yang meliputi jurusan pendidikan kepelatihan olahraga
20 orang, pendidikan olahraga 20 orang dan ilmu olahraga 20 orang. Berdasarkan hasil penelitian yang
telah dilakukan, diperoleh kesimpulan bahwa rata-rata pengetahuan alat gym ball adalah 3,71 termasuk
dengan kategori Cukup, rata-rata pengetahuan jenis latihan gym ball adalah 2,45 termasuk dalam kategori
Cukup, rata-rata pengetahuan teknik latihan gym ball adalah 0,85 termasuk dalam kategori Cukup, dan
rata-rata pengetahuan umum yang mempelajari gym ball adalah 0,97 termasuk dalam kategori Kurang. Jadi
kesimpulan dalam penelitian ini, pengetahuan tentang alat, jenis dan teknik mempunyai hasil yang sama
dan termasuk dalam kategori Cukup dan diketahui pengetahuan pengetahuan umum kurang dibanding
dengan pengetahuan alat, jenis, dan teknik.
KATA KUNCI: ABSTRACTS: The gym ball is a sport tools focus his practice on parts of the body such as the buttocks, thighs, lower back, abdominals, shoulders, and chest. The purpose of this study was to determine the knowledge of students of the Faculty of Sport Sciences State University of Surabaya on the tools, types, techniques and general knowledge that studies the gym ball. The method in this research is quantitative descriptive approach by examining the knowledge tools, types, techniques and general knowledge of students using the test questionnaire enclosed with using Guttman scale with samples used were 60 people that includes education majors coaching sports 20 people, physical education 20 and sports science 20 people. Based on the research that has been done, it is concluded that the average knowledge tool gym ball is 3.71 is including the category of Enough, the average knowledge of the type of exercise gym ball is 2.45 is included in the category of Enough, average knowledge of training techniques gym ball is 0.85 is included in the category of Enough, and the average common knowledge that studies the gym ball is 0.97 is included in the category of Less. So the conclusion in this study, knowledge of the tools, types and techniques have the same result and are included in the category of Enough and known knowledge common knowledge less than the knowledge tools, types, and techniquest.

KEYWORD:

gym ball, kind of gym exercise ball, gym ball exercise technique, Students

\section{PENDAHULUAN (Calibri 11 Bold)}

Perkembangan olahraga di dunia
berkembang sangat cepat, termasuk
perkembangan informasi, ilmu pengetahuan,
teknologi, seni, budaya, dan hak asasi manusia

begitu pesat sehingga menuntut kesiapan semua pihak untuk dapat menyesuaikan dengan segala kondisi yang ada (Kemenpora, 2014). Hal ini sangat nampak jelas dengan adanya aktifitas olahraga yang dilakukan oleh masyarakat, baik dari kalangan bawah, menenggah ataupun elit, 
tidak terkecuali mulai dari anak-anak, remaja, dewasa hingga lanjut usia. Olahraga tidak hanya sebagai sarana rekreasi, melainkan juga bermanfaat untuk mengurangi kemungkinan anak-anak tumbuh menjadi dewasa gemuk dan kurang sehat (Cassidy, dkk 2009).

Banyak manfaat yang di peroleh dari olahraga, salah satu manfaatnya yaitu menjaga kesehatan dan meningkatkan kebugaran jasmani, aliran darah menjadi lancar dan memperkuat otototot tubuh, apalagi bila latihan olahraga dilakukan dengan teratur. Latihan secara teratur memberikan manfaat bagi fisik dan kesehatan mental, serta memberikan faktor pelindung yang menguranggi timbulnya masalah kesehatan mental, serta memperkuat jantung dan otot-otot, mencegah penyakit, memberikan kontribusi untuk penurunan berat badan dan menyediakan tambahan energi untuk menyelesaikan tugas sehari-hari (Nelson, 2016).

Berdasarkan observasi pada beberapa dosen matakuliah fitness fakultas ilmu keolahragaan terkait dengan penggunaan ruang Achilles Sport Science and Fitness Center (ASSFC) maka diketahui sekilas bahwa mahasiswa hanya mengunakan weight training, treadmill dan senam aerobik, namun ternyata ada satu alat yang masih belum digunakan dalam proses pembelajaran yaitu gym ball. Gym ball adalah alat bantu olahraga umum ditemui di pusat-pusat latihan kebugaran. Penggunaannya sangat fleksibel. Bisa sambil berdiri, jongkok, duduk, tengkurap, maupun telentang. Fokus latihannya ada pada bagian-bagian tubuh seperti pantat, paha, punggung belakang, otot perut, bahu, hingga dada. Terbuat dari bahan karet lateksdan mampu menahan beban hingga $120 \mathrm{~kg}$ (Santoso, 2013). Penggunaan gym ball sangat efektif untuk melatih otot penyangga postur tubuh, perut dan punggung, sehingga membuat seseorang terlihat lebih tegak dan terlatih. Menurut Sundstrup menyatakan swiss ball direkomendasikan sebagai alat latihan untuk memperbaiki posisi sendi, postur, keseimbangan, dan umpan balik saraf. Namun, intensitas pelatihan yang tepat sulit diperoleh selama memakai swiss latihan bola, sedangkan latihan penguatan pada mesin biasanya dilakukan untuk mendorong tingkat tinggi aktivasi otot. (Sundstrup, dkk, 2012). Bola swiss terbukti mengurangi nyeri punggung dan cacat bila dibandingkan dengan latihan stabilitas inti di lantai. Dengan demikian, melakukan stabilitas inti latihan pada bola swiss mengurangi rasa sakit dan cacat sakit punggung rendah (Balakrishnan, dkk, 2016).

Banyak manfaat yang diperoleh melalui latihan gym ball seperti yang dikatakan (Ashadi, 2015) antara lain :

Meningkatkan keseimbangan Dengan bentuk bola yang bulat maka membuat gym ball mudah untuk mengelinding dan mudah berpindah posisi dengan mudah dan tidak stabil. Oleh sebab itu, latihan mengunakan gym ball dibutuhkan kemampuan untuk menyeimbangkan diri secara terus-menerus dan mengontrol otot-otot tubuh dengan baik agar bola gym ball tetap ditempat.

Melibatkan otot inti tubuh secara maksimal Dalam latihan gym ball otot perut dan punggung dipaksa secara aktif dari waktu ke waktu terlibat dalam upaya mencapai posisi seimbang dan mempertahankan posisi tubuh agar tidak bergerak atau jatuh. Sangat efektif untuk otot perut dan punggung.

Menguranggi resiko cidera Pengunaan gym ball dapat meningkatkan stabilitas sendi tulang belakang dan perifer sehingga memperkecil resiko cidera tubuh. Dengan beberap variasi gerakan dan alat tambahan misal dumbell maka gymball efektif untuk melatih otot-otot tubuh selain perut dan punggung, yaitu dada, lengan dan juga kaki.

Berdasarkan observasi pada beberapa
dosen matakuliah fitness fakultas ilmu keolahragaan terkait dengan penggunaan ruang Achilles Sport Science and Fitness Center (ASSFC) 
maka diketahui sekilas bahwa mahasiswa hanya mengunakan weight training, treadmill dan senam aerobik, namun ternyata ada satu alat yang masih belum digunakan dalam proses pembelajaran yaitu gym ball.

$$
\text { Padahal nantinya sangat mungkin }
$$
mahasiswa pendiddikan olahraga akan menempuh pengalaman magang atau saat bekerja di tempat fitness center atau senam aerobik. Disamping itu mereka dituntut untuk menguasai berbagai peralatan olahraga seperti penggunaan dumbell, barbel dan juga gym ball bahkan olahraga yang tidak menggunakan alat.

Fakta yang ada yaitu FIK unesa memiliki fasilitas berupa alat gym ball yang belum digunakan dalam perkuliahan pengembangan fitness dan senam aerobik. Sedangkan gym ball mulai popular dan banyak digunakan sebagai alat bantu olahraga di tempat-tempat fitness center dan sangar senam, serta belum diketahui seberapa baik pengetahuan mahasiswa FIK tentang alat olahraga gym ball. Dampaknya mahasiswa tidak memiliki dasar pengetahuan dan keterampilan tentang latihan fisik dengan alat bantu gym ball.

Dari penjelasan diatas permasalahan yang dapat disimpulkan yaitu terdapat beberapa mahasiswa yang tidak faham tentang alat olahraga gym ball, tetapi bukti itu tidak cukup kuat untuk menyatakan bahwa mahasiswa tidak mengetahui tentang gym ball. Hal yang menjadi pertanyaan yaitu apakah benar kondisinya di FIK Unesa seperti itu, karena tidak mengetahui fakta yang sesungguhya serta tidak ada data yang riil tentang pengetahuan mahasiswa FIK tentang alat olahraga gym ball. Oleh sebab itu perlu diadakan penelitian untuk memperoleh fakta tentang kondisi yang riil pengetahuan tentang gym ball.

Sehingga diperoleh solusi bahwa dengan diadakan penelitian ini untuk memperoleh data yang riil tentang pengetahuan mahasiswa FIK
Unesa tentang alat olahraga gym ball sehingga hasil penelitian ini bisa digunakan sebagai acuan untuk tindak lanjut dalam perkuliahan. Berdasarkan latar belakang di atas, maka penting dilaksanakan penelitian dengan judul Pengetahuan Mahasiswa FIK Universitas Negeri Surabaya Tentang alat Olahraga gym ball.

\section{METODE PENELITIAN (Calibri 11 Bold)}

Dalam penelitian ini menggunakan jenis penelitian kuantitatif dengan pendekatan deskriptif. Metode yang digunakan dalam proses pengambilan data penelitian ini adalah metode penelitian survei yang berusaha mengungkap fakta maupun kondisi sebenarnya dalam suatu lingkup dari jumlah besar subyek serta penelitian yang mengambil sampel dengan kriteria yang sudah ditentukan dengan menggunakan angket sebagai alat pengumpulan data pokok.

\section{Sasaran Penelitian}

Subjek penelitian ini adalah mahasiswa FIK Universitas Negeri Surabaya angkatan 2013 yang sudah memprogram mata kuliah fitness, penelitian ini hanya mengambil beberapa sempel dari populasi mahasiswa yang sudah memprogram mata kuliah fitness yaitu sejumlah 60 orang yang meliputi dari jurusan pendidikan kepelatihan olahraga 20 orang, jurusan pendidikan olahraga 20 orang dan ilmu olahraga 20 orang. Sesuai dengan pendapat (Arikunto, 2006), yang menyatakan bahwa apabila subjeknya kurang dari 100, lebih baik diambil semua hingga penelitiannya menggunakan penelitian populasi, jika jumlah subjeknya lebih besar dari 100 dapat diambil antara $10-15 \%$ atau $20-25 \%$ atau lebih. Dalam penelitian ini sampel diambil dengan teknik purposive sampling yaitu pengambilan sample yang ciri dan karakteristiknya sudah diketahui lebih dulu berdasarkan ciri dan sifat yang sudah diketahui (Maksum, 2012). 
Journal of Sport and Exercise Science, Vol 1, No 1, 2018 (01-07)

Pengetahuan Mahasiswa Fakultas Ilmu Keolahragaan Universitas Negeri Surabaya

Tentang Alat Olahraga Gym Ball

\section{Lokasi Penelitian}

Lokasi dalam penelitian ini yaitu di fakultas ilmu keolahragaan, pelaksanaan dlaksanakan pada tanggal 7-11 November 2016.

\section{Teknik Pengumpulan Data}

Teknik pengumpulan data yang akan digunakan dalam penelitian adalah :

1. Angket

Angket adalah serangkaian pertanyaan instrumen yang digunakan untuk mengungkap informasi, baik menyangkut fakta maupun pendapat (Maksum, 2012). Angket digunakan untuk alat ukur pengetahuan gym ball.

Metode pengumpulan data diantaranya:

a. Angket dibuat dengan pertanyaan yang benar-benar sama sehingga dapat di bagikan secara serentak kepada banyak responden.

b. Dapat dibuat anonim, sehingga responden bebas dan tidak malu menjawab.

Dalam penelitian ini digunakan angket langsung yang tertutup. Langkah- langkah pengumpulan angket sebagai berikut :

1. Peneliti membuat daftar pertanyaan dalam bentuk angket serta menentukan pertanyaan yang tepat.

2. Menentukan jadwal pertemuan untuk melakukan pengisian angket.

3. Menyebarkan angket kepada sampel untuk di isi.

4. Melakukan wawancara terstruktur sebagai pengecekan tambahan tentang angket yang telah di isi oleh sampel.
Tabel 1. Pertanyaan Wawancara Mahasiswa

\begin{tabular}{ll}
\hline No. & \multicolumn{1}{c}{ Pertanyaan } \\
\hline 1 & Apakah anda mengerti tentang bentuk spesifik \\
& alat olahraga gym ball yang meliputi bentuk, \\
& nama lain, manfaat, tempat latihan, \\
& karakteristik, pemilihan ukuran gym ball yang \\
& tepat, tekanan udara dan perawatan alat \\
& olahaga gym ball ? \\
\hline 2 & Apakah anda mengerti tentang jenis-jenis \\
& latihan gym ball yang meliputi jenis latihan \\
& untuk otot dada, otot perut, otot kaki, otot \\
& lengan, otot bahu dan otot punggung pada gym \\
& ball ? \\
\hline 3 & Apakah anda mengerti tentang teknik latihan \\
& gym ball yang meliputi teknik latihan untuk otot \\
dada, otot perut, otot kaki, otot lengan, otot \\
bahu dan otot punggung pada gym ball ?
\end{tabular}

5. Angket dikumpulkan dan menambahkan trigulasi data cek ricek seperti tabel dibawah ini:

Tabel 2. Pertanyaan Wawancara Mahasiswa

\begin{tabular}{lll}
\hline No. & \multicolumn{3}{c}{ Pertanyaan } \\
\hline 1 & $\begin{array}{l}\text { Apakah mahasiswa bapak/ ibu mengerti } \\
\text { tentang bentuk spesifik alat olahraga gym ball ? }\end{array}$ \\
\hline 2 & $\begin{array}{l}\text { Apakah mahasiswa bapak/ ibu mengetahui } \\
\text { tentang jenis-jenis latian gym ball ? }\end{array}$ \\
\hline 3 & $\begin{array}{l}\text { Apakah mahasiswa bapak/ ibu mengetahui } \\
\text { teknik latihan gym ball mengunakan alat } \\
\text { olahraga gym ball ? }\end{array}$ \\
\hline 4 & $\begin{array}{l}\text { Apakah mahasiswa bapak/ ibu pernah } \\
\text { mempelajari tentang alat olahraga gym ball ? }\end{array}$ \\
\hline 5 & $\begin{array}{l}\text { Apakah bapak/ ibu pernah memberikan materi } \\
\text { tentang alat olahraga gym ball ? }\end{array}$ \\
\hline
\end{tabular}

6. Menganalisis data sehingga mendapatkan data yang obyektif.

Angket mengunakan skala guttman yang digunakan untuk jawaban yang bersifat tegas (jelas) konsisten. Kriteria penilaian yang dipakai sebagai berikut :

Skor 1 untuk jawaban benar

Skor 0 untuk jawaban salah 


\section{Teknik Analisis Data}

Analisis data dalam penelitian ini menggunakan analisis deskriptif kuantitatif dengan persentase dengan mengunakan skala nominal. Statistik deskriptif adalah statistik yang berfungsi untuk mendeskripsikan atau memberi gambaran terhadap obyek yang diteliti melalui data sampel atau populasi sebagaimana adanya, tanpa melakukan analisis dan membuat kesimpulan yang berlaku untuk umum (Sugiyono, 2010). Adapun langkah-langkahnya sebagai berikut :

1. Menghitung Mean dengan rumus :

$$
\mathrm{X}=\frac{\Sigma \mathrm{X}}{\mathrm{N}}
$$

Keterangan :

$$
\begin{aligned}
& \mathrm{X}=\text { Mean } \\
& \sum \mathrm{X}=\text { Jumlah nilai } \mathrm{X} \\
& \mathrm{N}=\text { Jumlah individu/sampel }
\end{aligned}
$$

(Ali Maksum, 2007)

Data yang diperoleh melalui angket akan dianalisis dengan perhitungan program komputer SPSS (Statistical Package for Social Science) versi 21. Perhitungan tersebut dipergunakan untuk mengetahui pengetahuan mahasiswa FIK Universitas Negeri Surabaya tentang alat olahraga gym ball. Setelah mengetahui hasil pengetahuan mahasiswa FIK Universitas Negeri Surabaya maka hasilnya akan di rata-rata dan dipersentasekan dengan rumus persentase :

2. Menghitung Persentase Dengan rumus :

$$
\begin{aligned}
& \mathrm{P}=\frac{f}{n} \times 100 \% \\
& \text { Keterangan : } \\
& \mathrm{P}=\text { Presentase } \\
& \mathrm{f}=\text { Jumlah Frekwensi }
\end{aligned}
$$$$
\mathrm{n} \text { = Jumlah Sampel (Ali Maksum, 2007) }
$$

\section{HASIL}

Pada deskripsi data ini membahas tentang rata-rata dan persentase pengetahuan alat gym ball, jenis, teknik dan pengetahuan umum yang mempelajari gym ball.

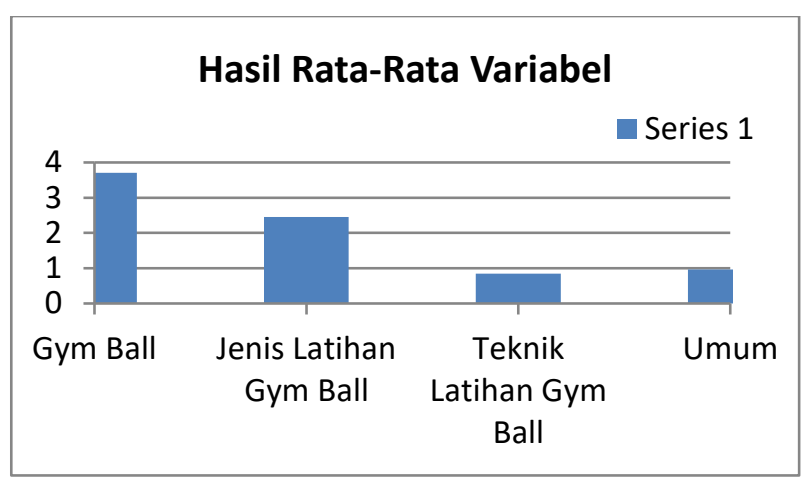

Grafik 1. Hasil rata-rata pengetahuan

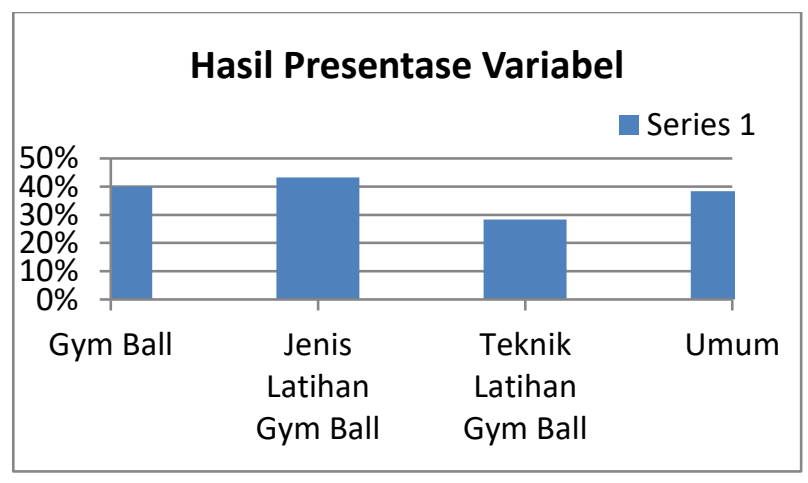

Grafik 1. Hasil rata-rata pengetahuan

\section{PEMBAHASAN}

Sesuai dengan rumusan masalah tentang pengetahuan alat gym ball, jenis, teknik dan pengatahuan umum tentang gym ball. Bab ini akan membahas mengenai rata-rata dan persentase pengetahuan alat olahraga gym ball, jenis latihan, teknik latihan gym ball dan pengetahuan umum yang mempelajari gym ball. Berdasarkan hasil dari kategori maka dapat disimpulkan bahwa : Rata-rata pengetahuan mahasiswa FIK Universitas Negeri Surabaya tentang alat gym ball termasuk kategori Cukup dengan rata-rata 3,71 dan persentase 40,00\%. Rata-rata pengetahuan mahasiswa FIK Universitas Negeri Surabaya tentang jenis latihan gym ball termasuk kategori Cukup dengan rata-rata 2,45 
dan persentase $43,33 \%$. Rata-rata pengetahuan mahasiswa FIK Universitas Negeri Surabaya tentang teknik latihan gym ball termasuk kategori Cukup dengan rata-rata 0,85 dan persentase 28,33\%. Rata-rata pengetahuan mahasiswa FIK Universitas Negeri Surabaya tentang pengetahuan umum yang mempelajari gym ball termasuk kategori Kurang dengan rata-rata 0,97 dan persentase $38,33 \%$

\section{SIMPULAN DAN REKOMENDASI}

Hasil penelitian mengenai pengetahuan mahasiswa FIK Universitas Negeri Surabaya tentang alat olahraga gym ball, maka akan disimpukan yaitu : Pengetahuan tentang alat olahraga gym ball mahasiswa FIK Universitas Negeri Surabaya diketahui memiliki rata-rata 3,71 dan persentase sebesar $40,00 \%$ berdasarkan klasifikasi norma kriteria termasuk dalam kategori Cukup. Pengetahuan tentang jenis latihan gym ball mahasiswa FIK Universitas Negeri Surabaya diketahui memiliki rata-rata 2,45 dan persentase sebesar 43,33\% berdasarkan klasifikasi norma kriteria termasuk dalam kategori Cukup. Pengetahuan tentang teknik laihan gym ball mahasiswa FIK Universitas Negeri Surabaya diketahui memiliki rata-rata 0,85 persentase sebesar $28,33 \%$ berdasarkan klasifikasi norma kriteria termasuk dalam kategori Cukup. Pengetahuan tentang alat olahraga gym ball mahasiswa FIK Universitas Negeri Surabaya diketahui memiliki rata-rata 0,97 persentase sebesar $38,33 \%$ berdasarkan klasifikasi norma kriteria termasuk dalam kategori Kurang.

Berdasarkan pada uraian penelitian, temuan dan simpulan di atas, maka dapat dikemukakan saran sebagai berikut : Secara umum banyak mahasiswa yang mengetahui tentang alat olahraga gym ball tetapi alat tersebut belum pernah digunakan oleh mahasiswa FIK untuk latihan olahraga khususnya pada saat proses perkuliahan, dengan ini diharapkan dosen memberikan pengetahuan tentang gym ball sehingga pada saat bekerja di tempat fitness atau sanggar senam dapat mempunyai pengalaman yang mumpuni. Mahasiswa FIK Universitas Negeri Surabaya masih banyak yang kurang mengetahui tentang jenis-jenis latihan gym ball, dikhawatirkan setelah lulus kuliah ingin bekerja di tempat fitness tidak mempunnyai pengalaman yang mumpuni akan membuat mmahasiswa tidak percaya diri untuk bekerja di tempat fitness. Banyak mahasiswa yang kebingungan dalam melakukan teknik latihan gym ball dikarenakan belum adanya pengetahuan gym ball melalui perkuliahan serta belum ada referensi buku gym ball berbahasa indonesia yang membuat mahasiswa semakin malas untuk membaca bahasa asing. Antusias mahasiswa dalam mempelajari gym ball sangat sedikit dikarenakan banyak mahasiswa yang belum tau tentang pengunaan dan manfaat mengunakan alat olahraga gym ball, diharapkan ada beberapa dosen yang memberikan pengetahuan gym ball sehingga mahasiswa setidaknya mengetahui dan bisa mendalaminya

\section{UCAPAN TERIMAKASIH}

Terimakasih penulis ucapkan kepada dosen pembimbing yang telah membimbing penulis sehingga penelitian ini dapat berjalan dengan apa yang telah direncanakan.

\section{REFERENSI}

Aagaard, M. Aarhus, MFE. Denmark. 2011. "Stability Ball Exercises Fitness and Performance Exercises For Strength, Stability and Flexibility" Publizon.

Anggraini, Dian. Dkk, 2014. Jurnal Olahraga Pendidikan. Asisten Deputi Olahraga Pendidikan Deputi Bidang Pembudayaan Olahraga Kementerian Pemuda dan Olahraga Republik Indonesia. Volume 1, Nomor 1, Mei 2014, Hal $32-46$.

Arikunto, Suharsimi. 2006. Prosedur Penelitian Suatu Pendekatam Praktik (Edisi Revisi VI). Jakarta : PT. Rineka Cipta. 
Arikunto, Suharsimi. 2010. Prosedur Penelitian Suatu Pendekatam Praktik (Edisi Revisi 2010). Jakarta : PT. Rineka Cipta.

Ashadi, Kunjung, dkk. 2015. Cara Mudah latihan Gym Ball. Surabaya: CV RIZKI AULIA GROUP.

Aspuah, Siti. 2013. Kumpulan Kuisioer Instrumen Penelitian Kesehatan. Yogyakarta : Nuha Medika.

Balakrishnan, R. yazid, E. Mahat, MFB. 2016. Effectiveness of the core stabilization exercise on floor and Swiss ball on individual with non-Specific low back pain. International Journal of Physical Education Sports and Health. Volume 2, Number 1. Page 347-350.

Bryden, Lincoln. 2009. Stability Ball Exercises. Canterbury Road. Bapchild.

Cassidy, Tania. Jones, Robin. Potrac, Paul. 2009. "Understanding Sports Coaching". London andNew York. British Library.

Cug, Mutlu. 2012. Efferts Of Swiss Ball Training On Knee Joint Reposition Sense, Core Strength And Dynamic Balance In Sedentary Collegiate Students. The Graduate Schooll Of Social. Sciences Of Middlee East technical University. Escamilla-Rafael, dkk. 2010." Core Muscle Activation During Swiss Ball and Traditional Abdominal Exercises". Journal of orthopaedic \& sports physical therapy. Vol. 40 (5): hal. 268.

Irez, G,B. Ozdemir, R, A. Evin, R. Irez, S, G. Korkusuz, F. 2011. "Integrating Pilates exercise into an exercise program for 65+ year-old women to reduce falls". Journal of Sports Science and Medicine. Vol. 10. Hal 105- 111.

Mahardika, I Made Sriundy. 2010. Pengantar Evaluasi Pengajaran. Surabaya : UNESA University Press.

Maksum, Ali. 2007. Buku Ajar Statistik. Surabaya. UNESA University Press.

Maksum, Ali. 2012. Metodologi Penelitian Dalam Olahraga. Surabaya. FIK Universitas Negeri Surabaya.
Nelson, C. Cromwell, S. 2016. Benefits of Exercise on Mind Function. Utah State University.

Ratmawati,Y. Setiawan. Kuntono, H.P. 2015. Pengaruh latihan Swiss Ball Terhadap Peningkatan Fleksibilitas Trunk Pada Remaja Putri Usia 17-21 Tahun. Jurnal Terpadu IImu Kesehatan, Volume 4, Nomor 1, hlm. 19-22.

Siregar, Sofian. 2013. Metode Penelitian Kuantitatif. Jakarta. Kencana, PT.Fajar Interpratama Mandiri.

Sugiyono, 2010. Statistika Untuk Penelitian. Bandung : Penerbit Alfabeta.

Sugiyono, 2013. Metode Penelitian Pendidikan Pendekatan Kuantitatif, Kualitatif, dan R\&D. Bandung. Alfabeta.

Sugiyono, 2015. Statistika Untuk Penelitian. Bandung : Penerbit Alfabeta.

Sundstrup, Emil. 2012. Original Research Swiss Ball Abdominal Crunch With Added Elastic Resistance Is an Afeective Alternative To Training Machines. The International Journal of Sports Physical Therapy. Volume 7, Number 4. Page 372.

Tim Penyusun. 2014. Pedoman Penulisan dan Penilaian Skripsi. Surabaya: Unesa Press.

Walter, R. Thompson. 2012. Worldwide Survey Of Fitness Trends For 012. ACSM's Health \& Fitness Journal. VOL. 15/ NO. 6. Hal 16 
Journal of Sport and Exercise Science, Vol 1, No 1, 2018 (01-07)

Pengetahuan Mahasiswa Fakultas Ilmu Keolahragaan Universitas Negeri Surabaya Tentang Alat Olahraga Gym Ball 